\title{
Blood Glycoprotein Levels in Diabetes Mellitus
}

\author{
A. Jonsson and J. K. Wales \\ University Department of Medicine, Martin Wing, The General Infirmary at Leeds, Leeds, U. K.
}

Summary. Five glycoproteins have been measured in the blood of 145 diabetic patients with and without clinical evidence of complications. Patients with diabetic complications have higher glycoprotein levels particularly when expressed as a ratio to serum albumin levels. In 32 pairs of patients matched for age, sex, body weight, duration and treatment of diabetes, significantly higher haptoglobin, fibrinogen and caeruloplasmin levels were associated with the presence of diabetic complications, but blood glucose levels were not significantly different. $\beta$-lipoprotein levels were positively correlated with age and $\alpha_{2}$-macroglobulin levels with the duration of clinical disease, but the type of antidiabetic therapy administered did not significantly alter glycoprotein levels. It is suggested that rising levels of certain glycoproteins in the blood of diabetic patients may indicate the development of diabetic vascular complications, but a prospective study is required before it can be decided whether this change predates the clinical appearance of the complications.

Key words: Caeruloplasmin, diabetic complications, fibrinogen, blood glycoproteins, haptoglobin, lipoproteins, $\alpha_{2}$-macroglobulin.

Most proteins in the blood are glycoproteins. Most are synthesised in the liver and some have specific transport functions. Changes in the blood levels of glycoproteins are known to occur in acute illnesses, the so called "acute phase reactants" [1], but it has been suggested recently that increases in serum glycoproteins in diabetic patients may indicate the development of diabetic complications [2]. Such a prognostic indicator would be useful in view of the difficulty in correlating the conventional estimates of diabetic control, such as blood glucose levels, with the incidence of complications. Glycoproteins are also found in high concentrations in diabetic vascular lesions, particularly in the glomerulus $[3,4]$, although there is no evidence as yet that they are deposited from the blood. Indeed there is little information available about the interrelationships of tissue and blood glycoproteins.

We have measured the blood levels of five different glycoproteins in 145 diabetic patients and correlated the results with the incidence of diabetic complications and other clinical data.

\section{Material and Methods}

All the patients studied were regular attenders at the morning Diabetic Clinic of the Leeds General Infirmary. At a routine clinic visit details of weight, height, age, duration and treatment of their diabetes were noted. It was also recorded whether any patient had suffered any recent symptoms attributable to hypoglycaemia and a general enquiry was made about diabetic control. All patients with acute illnesses were excluded.

The presence of diabetic complications was determined by (a) light fundoscopy through a dilated pupil for retinopathy, (b) recurrent albuminuria, in the absence of any other pathology than diabetes, for nephropathy, (c) signs and symptoms attributable to diabetic neuropathy in the absence of other causes of such a neuropathy, and (d) signs and symptoms of arterial disease affecting the coronary, cerebral or leg arteries for macroangiopathy. Table 1 shows these clinical details. $56 \%$ of the patients had no complications, and $14 \%$ had more than one such complication. No patient was uraemic and no patient was excluded because of the results of these investigations. 
Table 1. Clinical details of the diabetic patients studied

\begin{tabular}{|c|c|c|c|c|}
\hline & \multirow[b]{2}{*}{$\begin{array}{l}\text { All } \\
\text { Patients }\end{array}$} & \multicolumn{3}{|c|}{ Treatment Groups } \\
\hline & & $\begin{array}{l}\text { Insulin } \\
+ \text { diet }\end{array}$ & $\begin{array}{l}\text { Oral drugs } \\
+ \text { diet }\end{array}$ & $\begin{array}{l}\text { Diet } \\
\text { alone }\end{array}$ \\
\hline $\begin{array}{l}\text { Number: } \\
\text { \% Females } \\
\text { \% Males }\end{array}$ & $\begin{array}{l}145 \\
57 \% \\
43 \%\end{array}$ & $\begin{array}{l}57 \\
44 \% \\
56 \%\end{array}$ & $\begin{array}{l}65 \\
65 \% \\
35 \%\end{array}$ & $\begin{array}{l}23 \\
61 \% \\
39 \%\end{array}$ \\
\hline $\begin{array}{l}\text { Mean age (Yr) } \\
\text { Female } \\
\text { Male }\end{array}$ & $\begin{array}{l}60 \pm 11.7 \\
56 \pm 15.2\end{array}$ & $\begin{array}{l}54 \pm 12.0 \\
48 \pm 15.8\end{array}$ & $\begin{array}{l}63 \pm 10.3 \\
63 \pm 10.6\end{array}$ & $\begin{array}{l}63 \pm 12.3 \\
63 \pm 8.7\end{array}$ \\
\hline \multicolumn{5}{|c|}{$\begin{array}{l}\text { Body Weight (Ideal } \\
\text { body weight }^{\mathrm{a}}=100 \% \text { ) }\end{array}$} \\
\hline $\begin{array}{l}\text { Female } \\
\text { Male }\end{array}$ & $\begin{array}{l}112 \pm 21.6 \\
104 \pm 14.4\end{array}$ & $\begin{array}{l}105 \pm 20.5 \\
100 \pm 11.9\end{array}$ & $\begin{array}{l}116 \pm 18.8 \\
111 \pm 15.8\end{array}$ & $\begin{array}{l}113 \pm 30.7 \\
106 \pm 15.3\end{array}$ \\
\hline $\begin{array}{l}\text { Mean duration of } \\
\text { diabetes (Yr) }\end{array}$ & $11 \pm 10.2$ & $18 \pm 11.4$ & $9 \pm 7.5$ & $3 \pm 0.7$ \\
\hline \multicolumn{5}{|c|}{ Incidence of complications } \\
\hline None & 81 & 35 & 34 & 12 \\
\hline Macroangiopathy & 48 & 12 & 26 & 10 \\
\hline Retinopathy & 21 & 12 & 8 & 1 \\
\hline Nephropathy & 4 & 4 & 0 & 0 \\
\hline Neuropathy & 14 & 11 & 3 & 0 \\
\hline
\end{tabular}

Means \pm SD

a Ideal body weight calculated from the data of Kemsley [5]

Of the 65 patients treated by diet and oral therapy 22 were taking biguanides (mainly metformin), 21 patients sulphonylureas (mainly chlorpropamide) and 22 patients both sulphonylurea and biguanide therapy.

The patients were selected at random from the clinic lists. Those patients who agreed to take part in this study had a venous blood sample withdrawn on average $2-3 \mathrm{hrs}$ post prandially. It had already been determined in 11 diabetic patients that there was no significant difference between fasting and $2-3 \mathrm{hrs}$ post prandial blood levels of the glycoproteins studied. This would be expected from a consideration of their biological half lives.

The five glycoproteins listed in Table 2 were measured in these samples by the methods listed in this Table. Fibrinogen levels were measured in plasma samples and the other four glycoproteins in serum ${ }^{1}$. The relative standard deviations of the replicates of these glycoproteins were plasma fibrinogen $-6.4 \%$, serum $\beta$-lipoproteins $-3.1 \%$, serum haptoglobin $3.6 \%$, serum caeruloplasmin $-4.1 \%$, and serum $\alpha_{2}$-macroglobulin $-4.7 \%$. Whole blood glucose levels

\footnotetext{
1 When the glycoproteins are referred to as a group they are called the 'blood' glycoproteins, but individual glycoproteins as serum or plasma as is applicable.
}

were measured by a standard automated glucose oxidase method and serum albumin levels by the Technicon $\mathrm{N}-15 \mathrm{c}$ method.

All statistical analyses were calculated using an Olivetti P652 desk top computer including standard deviation, linear correlation analyses, and both paired and unpaired ' $t$ ' tests. The level of significance was taken at the $95 \%$ limit.

\section{Results}

In the 145 diabetic patients only $\beta$-lipoprotein levels showed a significant positive correlation with age $(\mathrm{r}=$ $0.251 ; \mathrm{p}<0.025$ ). Also $\beta$-lipoprotein levels were significantly higher in patients treated by diet alone and diet and oral agents, but these patients were older (Table 3). $\beta$-lipoprotein levels were also higher in females and these treatment groups contained more women. Caeruloplasmin levels too were significantly higher in females. It was concluded, therefore, that the type of antidiabetic treatment had little effect on glycoprotein levels.

Haptoglobin levels were positively correlated with body weight in the whole group $(\mathrm{r}=0.283 ; \mathrm{p}<0.01)$, but particulariy strongly in the group of patients receiving oral therapy $(\mathrm{r}=0.544 ; \mathrm{p}<0.001) . \alpha_{2}$-macroglobulin levels were positively correlated with the duration of clinical diabetes in the whole group of patients $(\mathrm{r}=0.259 ; \mathrm{p}<0.025)$ but not in any particular treatment group.

$44 \%$ of the patients had clinical diabetic complications and their blood levels of haptoglobin, fibrinogen and $\alpha_{2}$-macroglobin were significantly higher and the serum albumin levels significantly lower compared with the levels in the non-complicated patients (Table 4). The group of patients with diabetic complications were then further subdivided into 3 subgroups; the first of 35 patients with macroangiopathy, the second of 9 patients with retinopathy alone and a third group of 20 patients with multiple complications. When compared to the non-complicated group of patients, the patients with retinopathy showed no significant difference in any glycoprotein level, but the number of patients was small. The other two groups both had significantly higher haptoglobin and fibrinogen levels, while the group with macroangiopathy also had significantly higher $\beta$-lipoprotein levels (Table 4 ).

From the total group of 145 patients, it was possible to make up 32 pairs of patients matched for age, sex, body weight, duration and treatment of their diabetes and differing by the presence of absence of diabetic complications. Using the Wilcoxon rank sign test the blood levels of the glycoproteins, glucose and serum albumin could then be compared. Levels of 
Table 2. Details of glycoproteins measured

\begin{tabular}{|c|c|c|c|c|c|}
\hline & Mol. Wt: & $\begin{array}{l}\text { Mean hexose } \\
\text { content }\end{array}$ & Half life days & Biological function & Method of estimation \\
\hline Haptoglobin & $100 \times 10^{3}$ & $11.3 \%$ & $2-4$ & Binds haemoglobin & $\begin{array}{l}\text { Semi-automated } \\
\text { Shepherd and Jonsson [6] }\end{array}$ \\
\hline Caeruloplasmin & $160 \times 10^{3}$ & $3.0 \%$ & 4.3 & $\begin{array}{l}\text { Oxidase act., copper } \\
\text { transport }\end{array}$ & Radial immunodiffusion [7] \\
\hline Fibrinogen & $341 \times 10^{3}$ & $2.3 \%$ & 3.4 & Fibrin precursor & Ratnoff and Menzie [8] \\
\hline$\alpha-_{2}$ nacroglobulin & $820 \times 10^{3}$ & $3.6 \%$ & 5.0 & $\begin{array}{l}\text { Anti-plasmin, anti-trypsin, } \\
\text { insulin binding }\end{array}$ & Radial immunodiffusion [7] \\
\hline$\beta$-lipoprotein & $3.2 \times 10^{6}$ & $5.9 \%$ & 3.3 & Lipid transport & Semi-automated $[9,10]$ \\
\hline
\end{tabular}

Table 3. Glycoprotein and Glucose levels in diabetic patients studied (mean $\pm \mathrm{SE}$ )

\begin{tabular}{|c|c|c|c|c|c|}
\hline & & \multirow[b]{2}{*}{$\begin{array}{l}\text { All } \\
\text { patients }\end{array}$} & \multicolumn{3}{|c|}{ Treatment Groups } \\
\hline & & & $\begin{array}{l}\text { Insulin } \\
+ \text { diet }\end{array}$ & $\begin{array}{l}\text { Oral drugs } \\
+ \text { diet }\end{array}$ & $\begin{array}{l}\text { Diet } \\
\text { alone }\end{array}$ \\
\hline Number of patients & & 145 & 57 & 65 & 23 \\
\hline Mean age (yr) & & $58 \pm 13.7$ & $51 \pm 13.4$ & $63 \pm 10.4^{\mathrm{a}}$ & $63 \pm 10.2^{\mathrm{a}}$ \\
\hline Blood glucose & $\mathrm{mmol} / \mathrm{l}$ & $9.2 \pm 0.38$ & $8.4 \pm 0.71$ & $10.5 \pm 0.5^{\mathrm{b}}$ & $7.5 \pm 0.52^{\mathrm{a}}$ \\
\hline Serum haptoglobin & $\mathrm{g} / 1$ & $1.40 \pm 0.05$ & $1.34 \pm 0.06$ & $1.48 \pm 0.08$ & $1.33 \pm 0.13$ \\
\hline Plasma fibrinogen & $\mathrm{g} / 1$ & $3.45 \pm 0.10$ & $3.36 \pm 0.18$ & $3.61 \pm 0.15$ & $3.26 \pm 0.10$ \\
\hline Serum $\beta$-lipoprotein & $\mathrm{g} / 1$ & $4.79 \pm 0.12$ & $4.38 \pm 0.18$ & $4.98 \pm 0.18^{\mathrm{a}}$ & $5.22 \pm 0.25^{\mathrm{a}}$ \\
\hline Serum caeruloplasmin & $\mathrm{g} / 1$ & $0.383 \pm 0.006$ & $60.386 \pm 0.011$ & $10.38 \% \pm 0.009$ & $0.365 \pm 0.14$ \\
\hline Serum $\alpha_{2}$-macroglobulin & $\mathrm{g} / \mathrm{l}$ & $2.98 \pm 0.07$ & $3.01 \pm 0.10$ & $2.96 \pm 0.11$ & $2.92 \pm 0.14$ \\
\hline
\end{tabular}

a Significantly higher $(p<0.05)$ than insulin treated group

b Significantly higher $(\mathrm{p}<0.05)$ than other two treated groups

Table 4. Mean blood glycoprotein levels in diabetic patients related to diabetic complications present ( \pm SE)

\begin{tabular}{|c|c|c|c|c|c|c|c|c|c|c|}
\hline & Total & $\begin{array}{l}\text { Age } \\
\text { (yrs) }\end{array}$ & $\begin{array}{l}\text { Duration of } \\
\text { diabetes } \\
\text { (yrs) }\end{array}$ & $\begin{array}{l}\% \text { Ideal } \\
\text { body } \\
\text { weight }\end{array}$ & $\begin{array}{l}\text { Serum } \\
\text { albumin } \\
\mathrm{g} / 1\end{array}$ & $\begin{array}{l}\text { Serum } \\
\text { haptoglobin } \\
\mathrm{g} / 1\end{array}$ & $\begin{array}{l}\text { Plasma } \\
\text { fibrinogen } \\
\text {-g/l }\end{array}$ & $\begin{array}{l}\text { Serum } \\
\beta \text {-lipo- } \\
\text { protein } \\
\mathrm{g} / 1\end{array}$ & $\begin{array}{l}\text { Serum } \\
\text { caerulo- } \\
\text { plasmin } \\
\mathrm{g} / 1\end{array}$ & $\begin{array}{l}\text { Serum } \\
\alpha_{2} \text {-macro } \\
\text { globulin } \\
\mathrm{g} / 1\end{array}$ \\
\hline No complications & 81 & 55 & 10 & $109 \%$ & 53 & $\begin{array}{r}1.29 \\
\pm 0.06\end{array}$ & $\begin{array}{r}3.19 \\
\pm 0.10\end{array}$ & $\begin{array}{r}4.63 \\
\pm 0.17\end{array}$ & $\begin{array}{r}0.375 \\
\pm 0.011\end{array}$ & $\begin{array}{r}2.86 \\
\pm 0.09\end{array}$ \\
\hline $\begin{array}{l}\text { Patients with compli- } \\
\text { cations as a whole }\end{array}$ & 64 & $61^{\mathrm{a}}$ & $13^{2}$ & $110 \%$ & $50^{\mathrm{a}}$ & $\begin{aligned} & 1.53^{\mathrm{a}} \\
\pm & 0.08\end{aligned}$ & $\begin{array}{r}3.80^{\mathrm{a}} \\
\pm 0.19\end{array}$ & $\begin{array}{r}4.99 \\
\pm 0.16\end{array}$ & $\begin{array}{r}0.396 \\
\pm 0.013\end{array}$ & $\begin{aligned} & 3.12^{\mathrm{a}} \\
\pm & 0.11\end{aligned}$ \\
\hline Multiple complications & 20 & 57 & $19^{\mathrm{a}}$ & $107 \%$ & $49^{\mathrm{a}}$ & $\begin{aligned} & 1.58^{\mathrm{a}} \\
\pm & 0.12\end{aligned}$ & $\begin{array}{r}4.40^{\mathrm{a}} \\
\pm 0.43\end{array}$ & $\begin{array}{r}4.56 \\
\pm 0.28\end{array}$ & $\begin{array}{r}0.410 \\
\pm 0.018\end{array}$ & $\begin{array}{r}3.42 \\
\pm 0.19\end{array}$ \\
\hline Macroangiopathy alone & $\mathrm{e} 35$ & $65^{\mathrm{a}}$ & 8 & $111 \%$ & $50^{\mathrm{a}}$ & $\begin{aligned} & 1.57^{\mathrm{a}} \\
\pm & 0.13\end{aligned}$ & $\begin{array}{r}3.68^{\mathrm{a}} \\
\pm 0.21\end{array}$ & $\begin{aligned} & 5.27^{\mathrm{a}} \\
\pm & 0.21\end{aligned}$ & $\begin{array}{r}0.400 \\
\pm 0.013\end{array}$ & $\begin{array}{r}2.96 \\
\pm 0.13\end{array}$ \\
\hline Retinopathy alone & 9 & 56 & $19^{\mathrm{a}}$ & $108 \%$ & 52 & $\begin{array}{r}1.26 \\
\pm 0.15\end{array}$ & $\begin{array}{r}2.91 \\
\pm 0.17\end{array}$ & $\begin{array}{r}4.90 \\
\pm 0.31\end{array}$ & $\begin{array}{r}0.350 \\
\pm 0.270\end{array}$ & $\begin{array}{r}3.11 \\
\pm 0.34\end{array}$ \\
\hline Matched pairs: & & & & & & & & & & \\
\hline No complications & 32 & 61 & 12 & $109 \%$ & 53 & $\begin{array}{r}1.25 \\
\pm 0.09\end{array}$ & $\begin{array}{r}3.27 \\
\pm 0.17\end{array}$ & $\begin{array}{r}4.43 \\
\pm 0.27\end{array}$ & $\begin{array}{r}0.373 \\
\pm 0.013\end{array}$ & $\begin{array}{r}2.82 \\
\pm 0.13\end{array}$ \\
\hline With complications & 32 & 61 & 12 & $109 \%$ & $50^{\mathrm{b}}$ & $\begin{aligned} & 1.53^{\mathrm{b}} \\
& \pm 0.09\end{aligned}$ & $\begin{aligned} & 3.75^{\mathrm{b}} \\
\pm & 0.15\end{aligned}$ & $\begin{array}{r}5.03 \\
\pm 0.24\end{array}$ & $\begin{array}{r}0.414^{\mathrm{b}} \\
\pm 0.011\end{array}$ & $\begin{array}{r}2.96 \\
\pm 0.18\end{array}$ \\
\hline
\end{tabular}

a Significantly different $(p<0.05)$ compared to results in non-complicated patients

$b$ Significantly different $(\mathrm{p}<0.05)$ comparing the results in matched pairs of patients 
Table 5. The ratios of individual glycoprotein levels to serum albumin levels in diabetic patients with and without complications $( \pm$ SD)

\begin{tabular}{|c|c|c|c|c|c|c|}
\hline & \multirow[b]{2}{*}{ Number } & \multicolumn{5}{|c|}{ Ratio of individual glycoprotein to serum albumin level } \\
\hline & & Haptoglobin & Fibrinogen & $\beta$-lipoprotein & Caeruloplasmin & $\alpha_{2}$-macroglobulin \\
\hline No complications & 81 & $25.1 \pm 10.4$ & $61.4 \pm 20.3$ & $88.7 \pm 30.4$ & $7.21 \pm 1.91$ & $54.6 \pm 15.2$ \\
\hline Complications & 64 & $32.4 \pm 19.3^{\mathrm{a}}$ & $78.6 \pm 27.9^{\mathrm{a}}$ & $100.6 \pm 24.8^{\mathrm{a}}$ & $8.14 \pm 2.30^{\mathrm{a}}$ & $63.4 \pm 18.0^{\mathrm{a}}$ \\
\hline Macroangiopathy & 35 & $34.1 \pm 23.6^{\mathrm{a}}$ & $77.7 \pm 37.7^{\mathrm{a}}$ & $106.4 \pm 24.7^{\mathrm{a}}$ & $8.29 \pm 2.46^{\mathrm{a}}$ & $60.7 \pm 17.8$ \\
\hline Multiple complications & 20 & $32.9 \pm 12.8^{\mathrm{a}}$ & $90.2 \pm 36.4^{\mathrm{a}}$ & $93.3 \pm 24.5$ & $8.47 \pm 1.96^{a}$ & $69.9 \pm 16.8^{\mathrm{a}}$ \\
\hline $\begin{array}{l}\text { Retinopathy alone } \\
\text { Matched pairs: }\end{array}$ & 9 & $24.2 \pm 8.34$ & $56.1 \pm 11.0$ & $94.1 \pm 16.0$ & $6.77 \pm 1.78$ & $59.5 \pm 17.9$ \\
\hline No complications & 32 & $26.1 \pm 10.1$ & $65.3 \pm 16.7$ & $84.6 \pm 29.0$ & $7.30 \pm 1.92$ & $54.9 \pm 15.4$ \\
\hline With complications & 32 & $33.6 \pm 11.3^{\mathbf{b}}$ & $75.2 \pm 18.3^{\mathrm{b}}$ & $105.1 \pm 27.3^{b}$ & $8.59 \pm 1.87^{b}$ & $60.5 \pm 15.0$ \\
\hline
\end{tabular}

a Significantly different $(\mathrm{p}<0.05)$ compared to results in non complicated patients

b Singificantly different $(\mathrm{p}<0.05)$ comparing the results in the matched pairs of patients

Table 6. Mean blood glycoprotein levels in groups of diabetic patients with different blood glucose levels at the time of blood sampling

\begin{tabular}{|c|c|c|c|c|c|c|c|}
\hline & & Number & $\begin{array}{l}\text { Serum } \\
\text { haptoglobin } g / 1\end{array}$ & $\begin{array}{l}\text { Plasma } \\
\text { fibrinogen } g / 1\end{array}$ & $\begin{array}{l}\text { Serum } \\
\beta \text {-lipoprotein } \mathrm{g} / 1\end{array}$ & $\begin{array}{l}\text { Serum } \\
\text { caerulo- } \\
\text { plasmin g/1 }\end{array}$ & $\begin{array}{l}\text { Serum } \\
\alpha_{2} \text {-macro- } \\
\text { globulin } \\
\mathrm{g} / 1\end{array}$ \\
\hline \multirow[t]{2}{*}{ 1. All patients } & $\begin{array}{l}\text { Blood glucose } \\
>10 \mathrm{mmol} / 1\end{array}$ & 57 & 1.41 & 3.68 & 4.99 & 0.407 & 3.23 \\
\hline & $\begin{array}{l}\text { Blood glucose } \\
<6 \mathrm{mmol} / 1\end{array}$ & 35 & 1.30 & $3.15^{\mathrm{a}}$ & $4.44^{\mathrm{a}}$ & $0.362^{\text {a }}$ & $2.88^{\mathrm{a}}$ \\
\hline \multirow{4}{*}{$\begin{array}{l}\text { 2. Patients } \\
\text { treated by } \\
\text { insulin \& diet }\end{array}$} & $\begin{array}{l}\text { Blood glucose } \\
>10 \mathrm{mmol} / 1\end{array}$ & 20 & 1.42 & 3.77 & 4.81 & 0.420 & 3.21 \\
\hline & $\begin{array}{l}\text { Blood glucose } \\
<6 \mathrm{mmol} / 1\end{array}$ & 20 & 1.28 & 2.97 & $3.90^{\mathrm{a}}$ & $0.366^{\mathrm{a}}$ & 2.95 \\
\hline & $\begin{array}{l}\text { No recent hypo- } \\
\text { glycaemic symptoms }\end{array}$ & 33 & 1.44 & 3.71 & 4.70 & 0.407 & 3.20 \\
\hline & \multicolumn{2}{|c|}{$\begin{array}{l}\text { Recent hypoglycaemic } 24 \\
\text { symptoms }\end{array}$} & $1.20^{\mathrm{a}}$ & $2.88^{a}$ & $3.94^{\mathrm{a}}$ & $0.358^{\mathrm{a}}$ & $2.76^{\mathrm{a}}$ \\
\hline
\end{tabular}

a Significant difference between groups with high and low blood sugars or with or without recent hypoglycaemic symptoms $(\mathrm{p}<0.05)$

haptoglobin, fibrinogen and caeruloplasmin were significantly higher and serum albumin levels significantly lower in those patients with diabetic complications, while the blood glucose levels measured at the same time were not significantly different. This would suggest that the increases in $\alpha_{2}$-macroglobulin and $\beta$-lipoprotein levels observed in the whole group of patients with diabetic complications are due to the duration of their clinical diabetes and their age, respectively.

McMillan [2] has suggested that more predictive information is gained if the ratio between an individual glycoprotein and the serum albumin level is calculated. Table 5 shows these ratios in the groups as shown in the preceding Table. The ratios of all glycoproteins to albumin are higher in the total group of diabetic patients with complications, but again the 9 patients with retinopathy alone show no significant change in any ratio. In the patients with macroangiopathy and multiple complications the ratios of haptoglobin, fibrinogen and caeruloplasmin to albumin are significantly higher and the $\beta$-lipoprotein ratios in macroangiopathic patients and $\alpha_{2}$-macroglobulin ratios in the multiple complication group were also significantly higher. In the 32 matched pairs of patients only the $\alpha_{2}$-macroglobulin to albumin ratios were not significantly raised.

We have made some attempt to correlate the blood levels of these glycoproteins in these patients with more conventional estimates of diabetic control. Table 6 shows the mean levels in patients grouped with $2-3$ hrs post-prandial blood glucose levels below 
$6 \mathrm{mmol} / 1(108 \mathrm{mg} / 100 \mathrm{ml})$ and above $10 \mathrm{mmol} / 1(180$ $\mathrm{mg} / 100 \mathrm{ml}$ ). Significantly lower levels of fibrinogen, $\beta$-lipoprotein, caeruloplasmin and $\alpha_{2}$-macroglobulin are found with lower blood glucose levels irrespective of the type of antidiabetic treatment.

When the insulin-treated patients alone are considered by the same criteria, there are lower levels of all the glycoproteins, but only the $\beta$-lipoprotein and caeruloplasmin levels are significantly different. However, if the insulin-treated group is divided according to the presence or absence of recent hypoglycaemic symptoms then all glycoprotein levels are significantly lower in the hypoglycaemic patients (Table 6). These two groups are otherwise comparable as regards age, body weight and duration of diabetes, as well as the type of insulin used in therapy.

In the group of patients who had recent hypoglycaemic symptoms, the serum $\alpha_{2}$-macroglobulin levels were negatively correlated with blood glucose levels while in patients without hypoglycaemic symptoms serum $\alpha_{2}$-macroglobulin levels were positively correlated with serum albumin levels.

\section{Discussion}

From the management point of view, diabetes mellitus is a clinical disease having vascular complications with high morbidity. Therefore a simple predictive or prognostic indicator of these complications would be most useful in clinical management.

Interest in glycoprotein levels as such an indicator arises on 2 counts; (a) the addition of sugar residues onto the polypeptide chain of the glycoprotein is a post-ribososmal event, and providing glycosyltransferase activity is normal, the rate of glycoprotein synthesis and their constitution is likely to reflect the availability of sugar residues. This availability is likely to be higher in diabetes, particularly when poorly controlled, and glycoprotein synthesis may then be considered to be a major pathway of glucose metabolism in the liver which is not under the control of insulin [11]. (b) In view of their long vascular half lives, the blood glycoprotein levels are less likely to change rapidly by the hour (as is the blood glucose level) and may give a better indication of overall, long term control of the biochemical abnormalities of diabetes.

Most of the glycoproteins are contained in the $\alpha_{2}$-globulin fraction of the plasma proteins. Other workers have shown a relationship between an increased $\alpha_{2}$-globulin level and the presence of diabetic vascular complications $[12,13,14]$. In juvenile diabetic patients raised levels of serum haptoglobin have been reported in patients with angiopathy and in- creased haptoglobin levels have been shown to be associated with diabetic complications, but not with the duration of the diabetic state [15]. Both fibrinogen and $\beta$-lipoprotein levels, also, have been shown to be related to the incidence of diabetic complications [16]. As in this study, it has also been suggested that $\alpha_{2}$-macroglobulin levels were related to the duration of diabetes [15] although others have shown a progressive rise in $\alpha_{2}$-macroglobulin levels with an increasing incidence of diabetic vascular complications $[17,18,19]$.

Advances in biochemical analysis have made the measurement of circulating glycoproteins more reliable, but from the pathological point of view the levels of tissue glycoproteins are probably more important in diabetes and the relationship between serum and tissue glycoprotein levels requires further clarification. As recently suggested [20] abnormal levels of glycoprotein in the diabetic glomerular basement membrane can follow prolonged hyperglycaemia and may result in the development of diabetic glomerulosclerosis and renal failure. Similar changes may also occur in the liver and result in increased blood levels of glycoproteins.

As a result of the Boston Collaborative Drug Surveillance Programme [21] a relationship between recurrent hypoglycaemic attacks in patients receiving insulin and low serum haptoglobin levels was found. An explanation of this finding could be that, as in our patients with recent hypoglycaemic symptoms, both the serum haptoglobin and the $\alpha_{2}$-macroglobulin levels were reduced. As $\alpha_{2}$-macroglobulin has been shown to have some insulin-binding properties [22] hypoglycaemia may be facilitated.

Our results suggest that serum $\beta$-lipoprotein and $\alpha_{2}$-macroglobulin levels are not as reliable as the other glycoproteins measured in indicating the presence of diabetic complications, but from the results obtained from the group of matched pairs of patients haptoglobin, caeruloplasmin and particularly fibrinogen levels are more useful. We do not feel that an isolated measurement of a glycoprotein would be of great use, but serial measurements of these glycoproteins or glycoprotein/albumin ratios might be more predictive in the long term. Hovever, our results in the small number of patients with retinopathy alone do not suggest that these measurements would be of value in detecting this diabetic complication.

We must stress, however, that our results are retrospective; nevertheless we feel that a prospective study of these circulating glycoproteins in diabetic patients should be considered to see whether changes in blood glycoprotein levels do predate the clinically apparent diabetic vascular complications. 
Acknowledgements. We would like to thank Professor G. P. McNicol for his continued interest and support. A preliminary report of this work was presented to the Medical and Scientific Section of the British Diabetic Association at Sheffield in Spring, 1974.

\section{References}

1. Koj, A.: Structure and function of plasma proteins. Vol. 1., pp. 73-131. London: Plenum Press 1974

2. McMillan, D. E.: Association of diabetic microangiopathy with serum haptoglobin and albumin levels. Diabetes 27 (Suppl. 1), 289 (1973)

3. Ditzel, J.: Functional microangiopathy in diabetes mellitus. Diabetes 17, 388-397 (1968)

4. Goldenberg, S., Alex, M., Joski, R. A., Blumenthal, H. T.: Nonatheromatous peripheral vascular disease of the lower extremity in diabetes mellitus. Diabetes 8, 261-273 (1959)

5. Kemsley, W. F. F.: Body weight at different ages and heights. Ann. Eugen. (Lond.) 16, 316-334 (1951)

6. Shepherd, D., Jonsson, A.: A semiautomated method for the estimation of serum haptoglobin levels. Analyt. Biochem. (Submitted for publication 1976)

7. Mancini, G., Carbonara, A., Heremanns, J. F.: Immunochemical quantitation of antigens by single radial immunodiffusion. Immunochemistry 2, 235-254 (1965)

8. Ratnoff, O. D., Menzie, C.: A new methods for the determination of fibrinogen in small samples of piasma. J. Lab. clin. Med. 37, 316-320 (1951)

9. Bernsten, M., Samaille, J.: Dosage des $\beta$-lipoproteines seriques apres precipitation selective per L'heparine. Presse méd. 66, 974-975 (1958)

10. Watson, D.: A simple method for the determination of serum cholesterol. Clin. chim. Acta 5, 637-642 (1960)

11. Spiro, R. G.: Glycoproteins, structure, metabolism and biology. New Engl. J. Med. 269, 566-573, 616-621 (1963)

12. Schertenleib, F., Tuller, E. F.: Paper electrophoresis of serum proteins in diabetic patients. Diabetes 7, 46-52 (1958)

13. Ejarque, P., Marble, A., Tuller, E. F.: Proteins, lipoproteins and protein-bound carbohydrates in the serums of diabetic patients. Amer. J. Med. 27, 221-230 (1959)

14. McMillan, D. E.: Changes in serum proteins and protein bound carbohydrates in the serums of diabetic patients. Diabetologia 6, 597-604 (1970)

15. Bergstrand, C. G., Furst, P., Larsson, Y., Sterky, G.: Serum haptoglobin in juvenile diabetes. Scand. J. clin. Lab. Invest. 14, 629-632 (1962)

16. Ganrot, P. O., Gydell, K., Ekelund, H.: Serum concentration of $\alpha_{2}$-macroglobin, haptoglobin and $\alpha_{1}$-antitrypsin in diabetes mellitus. Acta endocr. (Kbh.) 55, 537-544 (1967)

17. Wardle, E. M., Piercy, D. A., Anderson, J.: Some chemical indices of diabetic vascular disease. Postgrad. med. J. 49, 1-9 (1973)

18. Cleve, H., Alexander, K., Mitzkat, J. H., Nissen, P., Salzmann, I.: Serum Glykoproteine beim Diabetes mellitus; quantitative immunologische Bestimmung von saurem $\alpha_{1}$-Gykoprotein, Gc, $\alpha_{2}$-Makroglobin und Hämopexin bei Diabetikern mit und ohne Angiopathien. Diabetologia 4, 48-55 (1968)

19. Müller, H., Kluthe, R.: Das Verhalten verschiedener Alpha Globuline beim Diabetes mellitus. Med. Klin. 66, 522-526 (1971)

20. Levin, N. W., Cortes, P., Silveira, E., Rubenstein, A. H.: Relation of renal growth to diabetic glomerulosclerosis. Lancet 1975 I, 1120-1121

21. Boston Collaborative Drug Surveillance Program: Relation between insulin induced hypoglycaemia and serum haptoglobin levels. Diabetes 23, 151-153 (1972)

22. Durr, H., Kallee, E.: Wechselwirkungen zwischen ${ }^{131}$ I-Insulin und $\alpha_{2}$-Macroglobulin. Hoppe-Seylers Z. physiol. Chem. 352, $629-634(1971)$

Received: November 6, 1975, and in revised form: March 30, 1976

Dr. J. K. Wales

Univ. Dept. of Medicine

Martín Wing

The General Infirmary at Leeds

Leeds LS1 3EX

England 